\title{
HEAT GAINS IN BUILDINGS - LIMIT CONDITIONS FOR CALCULATING ENERGY CONSUMPTION
}

\author{
Edmundas Monstvilas ${ }^{1}$, Karolis Banionis ${ }^{2}$, Vytautas Stankevičius ${ }^{3}$, \\ Jūratè Karbauskaité $\dot{4}^{4}$ Raimondas Bliūdžius ${ }^{5}$ \\ Institute of Architecture and Construction, Kaunas University of Technology, \\ Tunelio g. 60, LT-44405 Kaunas, Lithuania \\ E-mails: ${ }^{3}$ asi_monstvilas@yahoo.com; ${ }^{2}$ karolis_banionis@yahoo.com; \\ ${ }^{3}$ v.stankevicius@ktu.lt; ${ }^{4}$ jukarb@asi.lt; ${ }^{5}$ silfiz@asi.lt \\ Received 14 Jan. 2009; accepted 26 Febr. 2010
}

\begin{abstract}
The results of analysis presented in the paper are related to the certification of energy performance in buildings using calculation methods, when the real energy consumption of the building is not analyzed. Energy consumption for cooling is not examined. Heat transmission losses could be less than the sum of the heat gains of a building if building thermal insulation is sufficient. Currently, the whole amount of heat gains is included into calculation without the evaluation of time parameters. No limit conditions are specified in order to define surplus heat flows and the amount of heat flows so that energy performance of building is calculated. Thus, difference between heat gains and heat flows of a building could be negative. In the paper the basic formation schemes of heat gain access and accumulation are presented due to the presence of people and the bright period of the day. The most adverse circumstances are analyzed for the composition of the proposed schemes. The composition of estimating heat gains is the same for all categories of buildings. Calculation equations have been composed for the estimation of heat gains according to the basic formation schemes. The average monthly parameters of the heating season are used for calculation. The analysis of calculation has been done for the different categories of buildings in order to compare the results of building energy consumption when limit conditions for heat gains are estimated and vice versa. The analysis of different calculation methods of energy consumption has showed that limit conditions for heat gains are important to evaluate the calculation methodology of energy performance for building certification needs. It is important that the calculation methodology of energy performance for building certification would be universal for all EU member states. The presented limit conditions of the heat gains of a building could be used for improving calculation methods of energy consumption in the building certification process.
\end{abstract}

Keywords: building, energy performance, energy consumption, energy consumption schemes, certification, heat gains, heat losses, limit conditions of heat gains.

\section{Estimation aspects of internal and solar heat gains in buildings for energy performance certification purposes. A survey on literature references}

The implementation of building energy performance certification is one of the main elements in energy saving policy. Everybody agrees that the potential of energy saving in buildings is huge. The basic energy saving aspects are discussed in many references, for example in (Anderson et al. 2006; Horne 2006; Pulselli et al. 2006; Guan 2006; Zavadskas et al. 2008). The energy consumption analysis of different categories of buildings is given in (Biekša et al. 2006; Stankevičius et al. 2002; Stankevičius, Karbauskaite 2000). However, data about the estimation principles of possible heat gains in buildings (internal heat gains, heat gains due to the presence of people, solar heat gains through transparent building elements) and the limit conditions of heat gains are missing in these references.

The basics of building energy performance certification are closely related with the simulation of the energy consumption of a building. The energy performance of a building could be estimated by various methods: calculation, verification of calculation results with real energy consumption values, the use of real energy consumption values, etc. (LST EN 15217:2007). Each of the before mentioned estimation methods of energy performance is carefully analyzed in (Reddy 2006; Kreslins, BelindzevaKorkla 2003; Belindzeva-Korkla, Kreslins 2003; Wouters et al. 2003; Brandtweiner, Hoelt 2007; Mladin et al. 2006; Beccali et al. 1998; Stegou-Sagia et al. 2005; Stankevicius et al. 2007). However, the estimation principles of heat gains in buildings are not discussed in these papers.

The fundamental requirements for the estimation of heat gains (internal heat gains, heat gains due to the presence of people, solar heat gains through transparent building elements) are given in European standards (prEN 15203:2005; EN ISO 13790:2008; LST EN 15217:2007). Though, time parameters and limit conditions of heat gains are not included into calculation while the heat gains of a building are estimated. According to these standards, all types of heat gains should be used for the 
estimation of building heat gains. The utilization factor of heat gains is used in standard EN 13790:2008. This parameter is also determined without any restrictions on time.

The estimation of building energy performance could be done by the simplified method - using a energy consumption label of a building (Richalet et al. 2001; Gram-Hanssen et al. 2007; Corrado, Fabrizio 2006). While applying this method, the total energy consumption of a building is estimated without the exclusion of particular energy consumption components. Then, the energy performance of a building can be estimated in respect of other buildings in the same category. The total energy consumption balance of a building is evaluated employing this method. Nevertheless, it is impossible to distinguish separate components of heat gains in the energy consumption balance of a building.

Many software applications are used for simulation of energy consumption in the buildings, which are created based on different algorithms of energy consumption in the buildings. There is no single algorithm for assessment of energy consumption in the buildings. However, the above mentioned software allows evaluating the impact of various construction solutions (Jurelionis, Isevičius 2008; Lin, Zmeureanu 2006; Manioglu, Yilmaz 2006; Bazjanac 2004; Colomban et al. 2001; Bolton, Bell 2002), building mass (Gorgolewski et al. 2006), and the efficiency of heating and ventilation system on energy consumption in the building (Xie, Liu 2006; Teodosiu et al. 2006) and the impact of the amount of solar energy that gets into the building through transparent enclosures (Kaushika, Kumar 2004; Pappas et al. 2006) and layout structure of the building on energy consumption in the building (Ginevičius et al. 2008).

The suggestion to ground the analysis of energy performance on the second law of energy by assessing the quality of heat source and consumption efficiency is presented in (Wei, Zmeureanu 2006a, 2006b). The mathematical model created by their authors was realized using the Environmental and Engineering Solutions (EES). According to this mathematical model, the efficiency of energy consumption, exergy ratio and demand, and entropy demand. The amount of solar energy that gets into the building is also assessed in this calculation, but other heat gains are not discussed in more detail.

In some western countries, energy consumption for illuminations amounts to $20 \%$ of total initial amount of consumed energy and is second after energy consumption for heating, ventilation and air conditioning (Brodrick et al. 2002), solar radiation impact is analyzed in (Šeduikytè, Paukštys 2008). The use of automation and control can reduce the energy consumption for heating and air conditioning of the rooms by $25 \%$ and up to $20 \%$ with regard to the entire building (Waide 1996). It indicates the importance of assessing the heat gains in the balance of energy consumption in the building.

The impact of internal heat sources and efficiency of electric equipment on the energy performance of the building are partially generalized in (Kianifar, Rezazadeh 2006).
The performed analysis of the scientific studies indicates that in forming the unified calculation method for assessment of energy performance for buildings in the EU states, the principles of heat gains in the buildings have not been created yet and the procedure of assessment of the components of heat gains (heat emission from internal heat sources, heat gains due to the heat emitted by the people, the amount of solar energy that gets into the building through transparent enclosures) has not been defined.

\section{Theoretical background for the estimation of heat gains}

The total energy consumption in the building during the heating period for one square meter of the useful area of the building $\left(\mathrm{kWh} /\left(\mathrm{m}^{2} \cdot\right.\right.$ year $\left.)\right)$ is calculated according to the formula:

$$
\begin{aligned}
& \frac{\sum_{n}\left(Q_{n, e n v}+Q_{n, \text { vent }}+Q_{n, d 1}+Q_{n, \text { inf }}-Q_{n, e}-Q_{n, i . h . s .}-Q_{n, o}\right)}{\eta_{h . s .}}+ \\
& Q_{E}+Q_{\text {h.w. }} ; \\
& \eta_{\text {h.s. }}=\eta_{1} \cdot \eta_{2},
\end{aligned}
$$

where: $\eta_{\text {h.s. }}$ - efficiency coefficient of building heating system, by parts of unit; $\eta_{1}$ - efficiency coefficient of control devices in building heating system, by parts of unit; $\eta_{2}$ - efficiency coefficient of the heat supply source in building heating system, by parts of unit; $n$ - number of the heating seasons“ month; $Q_{n, e n v}-$ heat losses due to heat transmission through the building envelope during the considered month of the heating season, for $1 \mathrm{~m}^{2}$ of heated area $\left(\mathrm{kWh} /\left(\mathrm{m}^{2} \cdot\right.\right.$ month. $\left.)\right) ; Q_{n \text {,vent. }}$ - heat losses due to ventilation during the considered month of the heating season, for $1 \mathrm{~m}^{2}$ of heated area $\left(\mathrm{kWh} /\left(\mathrm{m}^{2} \cdot \mathrm{month}.\right)\right)$; $Q_{n, d 1}$ - heat losses due to entrance door opening during the considered month of the heating season, for $1 \mathrm{~m}^{2}$ of heated area $\left(\mathrm{kWh} /\left(\mathrm{m}^{2} \cdot\right.\right.$ month. $\left.)\right) ; Q_{n \text {,inf. }}-$ heat losses due to external air infiltration through cracks in the building envelope during the considered month of the heating season, for $1 \mathrm{~m}^{2}$ of heated area $\left(\mathrm{kWh} /\left(\mathrm{m}^{2} \cdot \mathrm{month}.\right)\right) ; Q_{n, e}$ - heat gains due solar radiation through transparent building elements during the considered month of the heating season, for $1 \mathrm{~m}^{2}$ of heated area $\left(\mathrm{kWh} /\left(\mathrm{m}^{2} \cdot \mathrm{month}.\right)\right) ; Q_{n, i . h . s}-$ heat gains due to internal heat sources during the considered month of the heating season, for $1 \mathrm{~m}^{2}$ of heated area (kWh/(m² $\cdot$ month.)); $Q_{n, o}$ - heat gains due to people presence during the considered month of the heating season, for $1 \mathrm{~m}^{2}$ of heated area ( $\mathrm{kWh} /\left(\mathrm{m}^{2} \cdot\right.$ month. $\left.)\right) ; Q_{E}-$ annual electricity consumption, for $1 \mathrm{~m}^{2}$ of heated area (kWh/(m².month.)); $Q_{\text {h.w. }}$ - annual energy consumption due to domestic hot water for $1 \mathrm{~m}^{2}$ of heated area $\left(\mathrm{kWh} /\left(\mathrm{m}^{2} \cdot \mathrm{month}\right)\right)$.

The equation (1) can be supplemented by other terms describing energy consumption and energy inflow, e.g. energy consumption for cooling the building can be 
assessed, etc. In our presented case, the formula (1) provides for the calculation using average parameters of the month. Naturally, the reduction of the calculated time intervals will improve the precision of calculation.

The temporal parameters of heat gains into the building were not covered in (prEN 15203:2005), (EN ISO 13790:2008) when assessing energy performance of the building. Limit conditions for assessing surplus heat gains and the amounts of heat gains that have to be included in the calculation of energy consumption in the building were not discussed either. Therefore, using the equation (1), all amounts of heat gains emitted in the building or getting in from the outside are assessed.

When calculating total energy consumption in the building, it is assessed that the buildings suffer a range of heat loss: through enclosures, due to ventilation, opening the front door, through linear thermal bridges, due to surplus outside air infiltration, etc. Alongside occur heat gains inside the building, which can partially or fully compensate the building's heat loss. These heat gains usually occur due to heat emissions from inside sources of heat, due to heat gains from outside (solar radiation) and due to the heat emitted by the people. During the day, the above mentioned heat gains can occur at different time or all at once. The heat gains throughout the day depend on the purpose of the building and the habits of building users.

When performing the calculations of energy performance certification for the buildings, the same calculation methods are applied to the buildings of different purpose and therefore, the unified scheme of heat gains during the day would be most convenient to use. This scheme could describe the most advantageous and disadvantageous cases of heat gains. If the advantageous case of heat gains is selected for the scheme, the heat gains into the building could be sufficient to cover the heat loss of the building and the result of calculating energy consumption of the building could be that the building does not require heating throughout the heating period. However, such scheme of heat gains would represent only individual cases of building use or user's behavior, because in reality, the building still has to be heated at certain time during the heating period and energy consumption for heating occurs. In our opinion, using the disadvantageous case of heat gains for assessing the heat consumption in the building would be more appropriate, i.e. according to the largest possible case of heat consumption in the building.

When creating the scheme of disadvantageous heat gains in the building that describes the largest possible heat consumption in the building, the following conditions were adopted:

- heat gains due to solar radiation through transparent building elements $Q_{n, e}$ are generated during the daylight hours;

- heat gains due to internal heat sources $Q_{n, \text { i.h.s }}$ are expected to last all day;

- heat gains due to people presence $Q_{n, o}$ are generated during people presence time in a building which begins as the daylight hours.
Meanwhile, heat loss through enclosures $Q_{n, e n v}$, heat loss due to ventilation $Q_{n \text {,vent. }}$, heat loss due to opening the front door $Q_{n, d 1}$, heat loss due to surplus outside air infiltration thorough the windows and front door $Q_{n \text {,inf. }}$ Occur throughout the day and it is assumed that the above mentioned loss does not vary throughout the day.

Fig. 1 presents our created average monthly scheme of disadvantageous heat gains in the building throughout the day. According to this scheme, heat gains due to heat emission from internal heat sources are constant throughout the day. After the sun rises, the heat gains increases due to the solar radiation that gets into the building. Heat gains increases further due to the heat emitted by the people.

\section{Calculation of internal heat gains}

When forming limit conditions related to heat less and heat gains in the building, most convenient is to start from the heat gains that occurs throughout the day, i.e. heat gains from internal heat sources $Q_{n, \text { i.h.s. }}$.

Heat gains due to heat emissions from internal heat sources $Q_{n, \text { i.h.s. }}\left(\mathrm{kWh} /\left(\mathrm{m}^{2} \cdot\right.\right.$ year $\left.)\right)$ during a particular month of the heating period is regularly calculated according to the formula (EN ISO 13790:2008):

$$
Q_{n, i . h . s .}=0,001 \cdot 24 \cdot g_{v} \cdot T_{n, h . s .},
$$

where: 0,001 - transfer multiplier from $\mathrm{W}$ into $\mathrm{kW}$; $T_{n, h . s}$ - duration of a considered month of the heating season, (days); 24 - duration of a day, (h); $g_{v}$ - heat gains from internal heat sources, for $1 \mathrm{~m}^{2}$ of the heated area of a considered building, $\left(\mathrm{W} / \mathrm{m}^{2}\right)$.

When performing the calculation of energy performance of the buildings, the temperature of all rooms in the building is set as constant during the heating period. If the amount of thermal energy larger than the heat loss of the building gets into the building, this amount of energy increases the temperature of rooms, i.e. overheats the rooms.

Equation (3) is correct only when the building gains the amount of thermal energy that can be withdrawn through the enclosures or otherwise.

To evaluate the heat gains due to heat emissions from internal heat sources $Q_{n \text {,i.h.s. } 1},\left(\mathrm{kWh} /\left(\mathrm{m}^{2} \cdot \mathrm{month}\right)\right.$ during the particular month of each heating period the following limit conditions are suggested for calculations: If

$$
\left(Q_{n, \text { env }}+Q_{n, \text { vent }}+Q_{n, d 1}+Q_{n, \text { inf }}\right) \leq 0,001 \cdot 24 \cdot g_{v} \cdot T_{h . s .},
$$

then

$$
Q_{n, i . h . s .1}=\left(Q_{n, e n v}+Q_{n, v e n t}+Q_{n, d 1}+Q_{n, \text { inf }}\right),
$$

in other cases

$$
Q_{n, i . h . s .1}=0,001 \cdot 24 \cdot g_{v} \cdot T_{n, h . s .} .
$$

The reduced need to heat the building due to heat emissions from internal heat sources $Q_{n \text {,i.h.s.1, }}$ ( $\mathrm{kWh} /\left(\mathrm{m}^{2} \cdot \mathrm{month}\right)$ during the particular month of each heating period $Q_{n}{ }^{I},\left(\mathrm{kWh} /\left(\mathrm{m}^{2} \cdot\right.\right.$ month $\left.)\right)$ is calculated as follows: 
a)

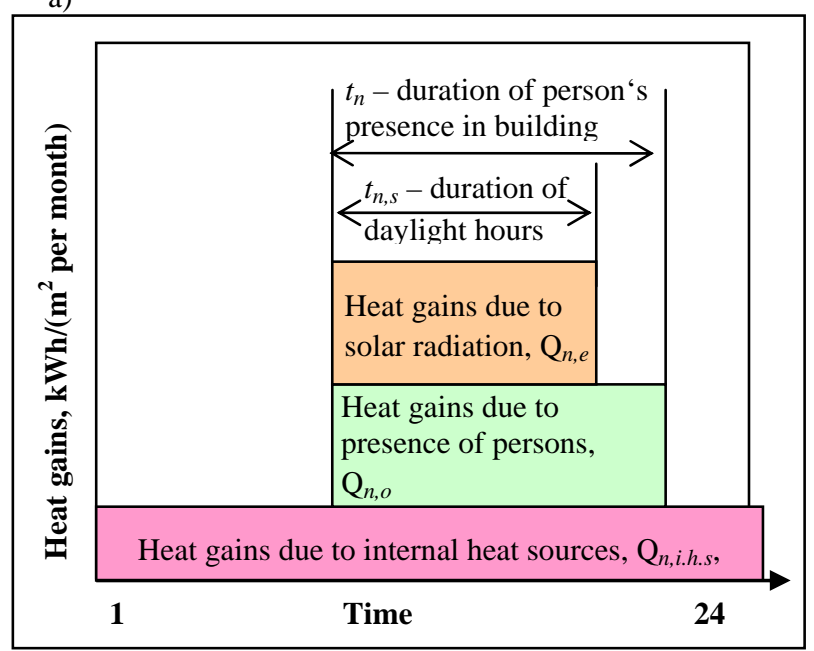

b)

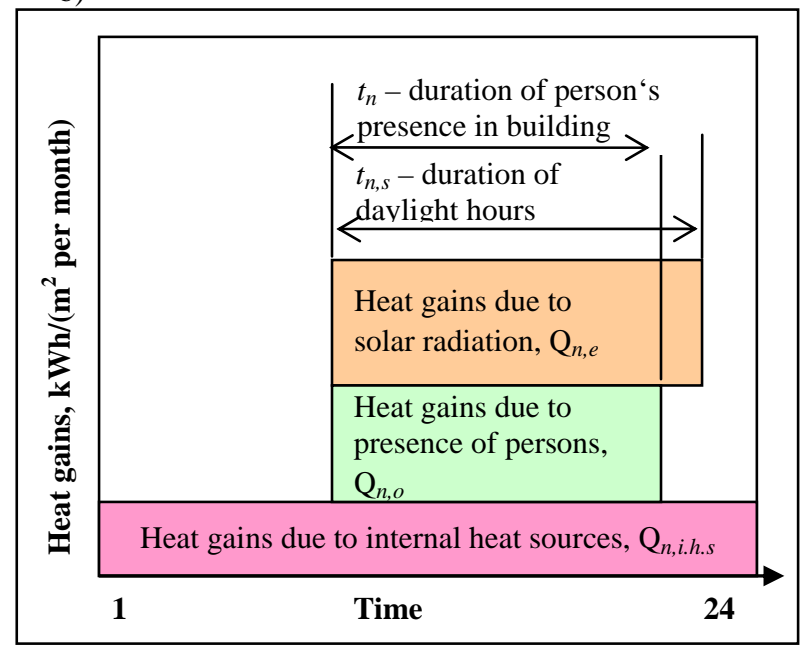

Fig. 1. Average monthly schemes of heat gains into the building during the day, depending on the time of presence of people in the building during the day and the duration of daytime: a - the case when the time of presence of people in the building during the day is longer than the duration of daytime, $b$ - the case time of presence of people in the building during the day is shorter than the duration of daytime

$$
Q_{n}{ }^{I}=Q_{n, \text { env }}+Q_{n, v e n t}+Q_{n, d 1}+Q_{n, \text { inf }}-Q_{n, \text { i.h.s. } 1} \text {. }
$$

The limit conditions defined by equations (4)-(6) can be described as follows:

a) heat gains due to internal heat sources are generated constantly all day;

b) if heat gains due to internal heat sources are larger or equal to the total heat losses of a considered building, (left part of the equation (4)), the surplus of the heat energy is removed from the building (equation (5));

c) if heat gains due to internal heat sources are less than the total heat losses of a considered building, (left part of the equation (4)), the total amount of heat gains is included into energy consumption of a building (equation (6)).

\section{Calculation of heat gains from the outside}

If energy consumption for cooling the building is not evaluated in calculating energy consumption of the building, heat gains from the outside is assessed only during the heating period. When calculating heat gains from the outside (prEN 15203:2005), the amount of solar radiation energy that gets into the building through transparent enclosures is evaluated. The heat gains into the building $Q_{n, e},\left(\mathrm{kWh} /\left(\mathrm{m}^{2} \cdot \mathrm{month}\right)\right)$ during each month of the heating period is regularly calculated according to the equation:

$$
\begin{aligned}
Q_{n, e}= & \frac{F_{F}}{K_{t} \cdot A_{p}} \cdot \sum\left(A_{w d . e} \cdot q_{n, e} \cdot g\right)= \\
& \frac{0,67}{A_{p}} \cdot \sum\left(A_{w d . e} \cdot q_{n, e} \cdot g\right),
\end{aligned}
$$

where: $q_{n, e}$ - the total amount of solar radiation heat through $1 \mathrm{~m}^{2}$ of a transparent building element of given orientation for each month of heating season $\left(\mathrm{kWh} /\left(\mathrm{m}^{2} \cdot \mathrm{month}\right)\right)$. This total amount of solar radiation heat is determined by the sum of reflected, direct and diffused solar energy amounts (which are radiated to surfaces of given orientation) during average cloudy day;
$A_{w d . e}$ - area of transparent building element of the given orientation, $\left(\mathrm{m}^{2}\right)$; $A_{p}$ - heated area of a considered building, $\left(\mathrm{m}^{2}\right) ; g$ - coefficient of total solar energy transmittance of transparent building elements; $F_{F}$ - coefficient of glazing part of the transparent building element's orifice; default value is equal to 0,$8 ; K_{t}$ - coefficient of the transparent building element's shading due to other buildings in neighborhood, default value is equal to 1,2 .

When performing the calculation of energy performance of the buildings, the temperature of all rooms in the building is set as constant during the heating period. If the amount of thermal energy larger than the need of energy to heat the building $Q_{n}{ }^{I}$, this amount of energy increases the temperature of rooms, i.e. overheats the rooms. Thus, the calculations have to provide that the surplus thermal energy is eliminated from the building. They must also provide that the sun is radiating thermal energy only for a part of day. After the sun sets, there is no heat gain. The equation (8) is correct only when the building gains the amount of thermal energy that can be withdrawn through the enclosures or otherwise and if the sun was shining throughout the day. In order to avoid the above mentioned inaccuracies, to calculate the heat gains from the outside $Q_{n, e .1},\left(\mathrm{kWh} /\left(\mathrm{m}^{2} \cdot \mathrm{month}\right)\right)$ during the particular month of each heating period the following limit conditions are suggested:

$$
\begin{gathered}
\text { If } \quad \frac{t_{n, s}}{24} \cdot Q_{n}{ }^{I} \leq \frac{0,67}{A_{p}} \cdot \sum\left(A_{w d . e} \cdot q_{n, e} \cdot g\right), \\
\text { then } \\
Q_{n, e .1}=\frac{t_{n, s}}{24} \cdot Q^{I},
\end{gathered}
$$

in other case $Q_{n, e .1}=\frac{0,67}{A_{p}} \cdot \sum\left(A_{w d . e} \cdot q_{n, e} \cdot g\right)$.

where: $t_{n, s}$ - average duration of daylight hours of the day per considered month, that means the time from the sunrise till the sunset, (h). 
The limit conditions defined by equations (9)-(11) can be described as follows:

a) if through transparent enclosures the building gains more (or equal) solar heat than can be eliminated from the building, it is assumed that the surplus heat is artificially eliminated from the building and only the heat gains is calculated in the energy consumption of the building that can be eliminated from the building during daytime in the form of heat loss;

b) if through transparent enclosures the building gains less solar heat than can be eliminated from the building in the form of heat loss, all solar heat gains is calculated in the energy consumption of the building.

It is noteworthy, that limit conditions defined by equations (9)-(11) describe heat loss and gains only during daytime. One must take into account that if there is no sun, the heat loss of the building does not decrease. Solar radiation heat gains can reduce total heat loss only during daytime. Therefore, heat loss reduction due to heat emissions from internal sources and solar thermal energy during the particular month of the heating period $Q^{I I}$, $\left(\mathrm{kWh} /\left(\mathrm{m}^{2} \cdot \mathrm{month}\right)\right)$ is calculated as follows:

$Q_{n}{ }^{I I}=\frac{24-t_{n, s}}{24} \cdot Q_{n}{ }^{I}+\left(\frac{t_{n, s}}{24} \cdot Q_{n}{ }^{I}-Q_{n, e .1}\right)=Q_{n}{ }^{I}-Q_{n, e .1}$,

where: $\left(24-t_{n, s}\right) / 24$ - multiplier for estimation of average monthly dark period of the day; $t_{n, s} / 24$ - multiplier for estimation of average monthly daylight hours.

\section{Calculation of heat gains due to the heat emitted by the people}

If energy consumption for cooling the building is not evaluated in calculating energy consumption of the building, heat gains due to the heat emitted by the people is assessed only during the heating period. The heat gains into the building due to the heat emitted by the people $Q_{n, o},\left(\mathrm{kWh} /\left(\mathrm{m}^{2} \cdot \mathrm{month}\right)\right)$ during each month of the heating period is regularly calculated according to the formula (LST EN 15217:2007):

$$
Q_{n, o}=0,001 \cdot \frac{A_{p}}{A_{o}} \cdot g_{o} \cdot t_{n} \cdot T_{n, h . s .} \cdot \frac{1}{A_{p}}=0,001 \cdot \frac{1}{A_{o}} \cdot g_{o} \cdot t_{n} \cdot T_{n, h . s .},
$$

where: 0,001 - transfer multiplier from $\mathrm{W}$ into $\mathrm{kW}$; $T_{n, h . s .}-$ duration of a considered month of the heating season, (days); $g_{o}$ - average energy flux from a person, (W/person); $t_{n}$ - average monthly duration of people presence in a building during the day (h); $A_{o}$ - heated area of a building for one person, $\left(\mathrm{m}^{2}\right)$.

When evaluating the heat gains due to the heat emitted by the people, an important part is played by the time of beginning of daytime and the time of beginning of people's presence in the room. As mentioned above, it is assumed that the beginning of people's presence in the room coincides with the beginning of daytime.

When evaluating heat gains due to the heat emitted by the people each month of the year $Q_{n, o .1}$, $\left(\mathrm{kWh} /\left(\mathrm{m}^{2} \cdot \mathrm{month}\right)\right)$, two limit conditions are required. The first limit condition described by the equations (14)-(16) defines the case when average time of people's presence in the building $t_{n}$ is not longer than average duration of daytime period per day $t_{n, s}$ :

If $t \leq t_{s}$ and

$$
Q^{I} \cdot \frac{t_{n}}{24}-Q_{e .1} \cdot \frac{t_{n}}{t_{n, s}} \leq 0,001 \cdot \frac{1}{A_{o}} \cdot g_{o} \cdot t_{n} \cdot T_{n, h . s .},
$$

then $Q_{o .1}=Q^{I} \cdot \frac{t_{n}}{24}-Q_{e .1} \cdot \frac{t_{n}}{t_{n, s}}$,

in other case $Q_{0.1}=0,001 \cdot \frac{1}{A_{o}} \cdot g_{o} \cdot t_{n} \cdot T_{n, h . s .}$.

If the time of people's presence in the building per day $t_{n}$ is not longer than the average duration of daytime period per day of the month $t_{n, s}$, due to heat emissions from internal sources of heat, solar radiation heat gains, and heat gains due to the heat emitted by the people, the need of energy for heating the building $Q^{I I I}$, $\left(\mathrm{kWh} /\left(\mathrm{m}^{2} \cdot \mathrm{month}\right)\right)$ is further reduced and calculated as follows:

$$
\begin{aligned}
Q_{n}{ }^{I I I}= & \frac{24-t_{n, s}}{24} \cdot Q^{I}+\left(\frac{t_{n, s}}{24} \cdot Q_{n}{ }^{I}-Q_{n, e .1}-Q_{n, o .1 .}\right)= \\
& Q_{n}{ }^{I}-Q_{n, e .1}-Q_{n, o .1},
\end{aligned}
$$

where: $\left(24-t_{n, s}\right) / 24-$ multiplier for estimation of average monthly dark period of the day; $t_{n, s} / 24$-multiplier for estimation of the average monthly daylight hours; $Q_{o .1}-$ value determined by (15) or (16) equations.

The second limit condition related to the time of people's presence in the building is described by the equations (18)-(26). It defines the case when average time of people's presence in the building $t_{n}$ is longer than average duration of daytime period per day of the month $t_{n, s}$ :

If $t_{n}>t_{n, s}$,

$Q_{n}{ }^{I} \cdot \frac{t_{n, s}}{24}-Q_{n, e .1} \leq 0,001 \cdot \frac{1}{A_{o}} \cdot g_{o} \cdot t_{n, s} \cdot T_{n, h . s .}$

and $Q_{n}{ }^{I} \cdot \frac{t_{n}-t_{n, s}}{24} \leq 0,001 \cdot \frac{1}{A_{o}} \cdot g_{o} \cdot\left(t_{n}-t_{n, s}\right) \cdot T_{n, h . s .}$,

then $Q_{n, o .1}=Q_{n}{ }^{I} \cdot \frac{t_{n, s}}{24}-Q_{n, e .1}+Q_{n}{ }^{I} \cdot \frac{t_{n}-t_{n, s}}{24}$.

If term by (18) equation is fulfilled and

$$
Q_{n}{ }^{I} \cdot \frac{t_{n}-t_{n, s}}{24}>0,001 \cdot \frac{1}{A_{o}} \cdot g_{o} \cdot\left(t_{n}-t_{n, s}\right) \cdot T_{n, h . s .},
$$

then

$$
Q_{n, o .1}=Q_{n}{ }^{I} \cdot \frac{t_{n, s}}{24}-Q_{n, e .1}+0,001 \cdot \frac{1}{A_{o}} \cdot g_{o}, \cdot\left(t_{n}-t_{n, s}\right) \cdot T_{n, h . s .} \text {. }
$$

If $t_{n}>t_{n, s}$,

$$
Q_{n}{ }^{I} \cdot \frac{t_{n, s}}{24}-Q_{n, e .1}>0,001 \cdot \frac{1}{A_{o}} \cdot g_{o} \cdot t_{n, s} \cdot T_{n, h . s .},
$$


and $Q_{n}{ }^{I} \cdot \frac{t_{n}-t_{n, s}}{24} \leq 0,001 \cdot \frac{1}{A_{o}} \cdot g_{o} \cdot\left(t_{n}-t_{n, s}\right) \cdot T_{n, h . s .}$,

then $Q_{n, o .1}=0,001 \cdot \frac{1}{A_{o}} \cdot g_{o} \cdot t_{n, s} \cdot T_{n, h . s .}+Q_{n}{ }^{I} \cdot \frac{t_{n}-t_{n, s}}{24}$.

In other cases: $Q_{n, o .1}=0,001 \cdot \frac{1}{A_{o}} \cdot g_{o} \cdot t_{n} \cdot T_{n, h . s .}$.

The equations (14)-(26) provide that if at the same time the solar radiation heat gets into the building plus heat is emitted from internal heat sources plus heat gains due to the heat emitted by the people occurs, the surplus heat can occur, which has to be eliminated from the building.

If the time of people's presence in the building per day $t$ is longer than the average duration of daytime period per day of the month $t_{s}$, due to heat emissions from internal sources of heat, solar radiation heat gains, and heat gains due to the heat emitted by the people, the reduced need of energy for heating the building $Q_{n}{ }^{I V}$, $\left(\mathrm{kWh} /\left(\mathrm{m}^{2} \cdot \mathrm{month}\right)\right)$ is calculated as follows:

$Q_{n}{ }^{I V}=\left(\frac{24-t_{n, s}}{24} \cdot Q^{I}-\frac{t_{n}-t_{n, s}}{t_{n}} Q_{o .1}\right)+$

$\left(\frac{t_{n, s}}{24} \cdot Q_{n}{ }^{I}-Q_{n, e .1}-\frac{t_{n, s}}{t_{n}} \cdot Q_{n, o .1}\right)=Q_{n}{ }^{I}-Q_{n, e .1}-Q_{n, o .1}$,

where: $Q_{n, o .1}$ - value obtained according to one of the equations (20), (22), (25) or (26).

As mentioned above, heat emissions from internal heat sources occur throughout the day, and solar radiation heat gains can reduce the heat loss of the building only during daytime. It can be evaluated by equation (1) of energy consumption of the building after correcting it according to the expression of equation (12). Meanwhile, the heat gain due to the heat emitted by the people is related to the time of people's presence in the building, which can be longer or shorter than the daytime period. Due to this reason, the expression of the equation of energy consumption of the building depends on the duration of people's presence in the building with regard to the duration of daytime. If the time of people's presence in the building during the day $t$ is not longer than the average duration of daytime per day $t_{s}$ :

If $t_{n} \leq t_{n, s}$, then:

$$
\begin{aligned}
Q_{\text {sum }}= & \frac{\sum_{n}\left(\frac{24-t_{n, s}}{24} \cdot Q_{n}{ }^{I}+\left(\frac{t_{n, s}}{24} \cdot Q_{n}{ }^{I}-Q_{n, e .1}-Q_{n, o .1}\right)\right)}{\eta_{h . s .}}+Q_{E}+Q_{h . w .} \\
& \frac{\left.\sum_{n} Q_{n, e n v}+Q_{n, v e n t}+Q_{n, d 1}+Q_{n, i n f}-Q_{n, i . h . s .1}-Q_{n, e .1}-Q_{n, o .1}\right)}{\eta_{h . s .}}+ \\
Q_{E}+Q_{h . w .}, &
\end{aligned}
$$

if $t_{n}>t_{n, s}$, then

$Q_{\text {sum }}=$

$\frac{\sum\left(\left(\frac{24-t_{n, s}}{24} \cdot Q_{n}{ }^{I}-\frac{t_{n}-t_{n, s}}{t_{n}} Q_{n, o .1}\right)+\left(\frac{t_{n, s}}{24} \cdot Q_{n}{ }^{I}-Q_{n, e .1}-\frac{t_{n, s}}{t_{n}} \cdot Q_{o .1}\right)\right)}{\eta_{h . s .}}+$

$Q_{E}+Q_{h . w .}=$

$\frac{\sum_{n}\left(Q_{n, e n v}+Q_{n, v e n t}+Q_{n, d 1}+Q_{n, \text { inf }}-Q_{n, i . h . s .1}-Q_{n, e .1}-Q_{n, o .1}\right)}{\eta_{h . s .}}+$

$Q_{E}+Q_{h . w .}$,

where in equations (28) and (29): $Q_{o .1}$ - value obtained according to one of the equations: (15), (16), (20), (22), (25) or (26).

The analysis of the components in the expression (29) testify that calculation of energy consumption $Q_{\text {sum }}$ in respect of heat gains due to internal heat sources $Q_{n, i . h . s 1}$, people‘s presence $Q_{n, o .1}$ and solar radiation $Q_{n, e .1}$ $Q_{n, e .1}$ should be defined in the other way than it is defined by (1) equation.

The equation (29) will be used for following analysis because it more exactly reflects the limit conditions of generation of heat gains of a building.

\section{Check calculations in order to establish the impact of set limit conditions on calculation results}

In order to assess the expedience of applying set limit conditions, check calculations of energy consumption in the buildings of various purposes were performed. In order to simplify the analysis of performed calculations, the object of the above mentioned calculations was a separate part of the building instead of the entire building. With the same purpose of simplification the following assumptions were made:

- the premise of $500 \mathrm{~m}^{2}$ useful (heated) area with only one outer enclosure was selected. The room adjoins other heated rooms on all other sides;

- the heat to the building is supplied from the district heating network, the heating station of the building is automatic, an external thermostat is installed, and thermostats are installed with each heating appliances in the building. The coefficient of efficiency of the heating system is $\eta_{\text {h.s. }}=1$;

- only the thermal energy supplied to the rooms is assessed, i.e. the consumption of primary energy is not assessed;

- the energy consumption for cooling the building is not assessed;

- only natural ventilation is installed in the rooms, i.e. mechanical ventilation and heat recuperators are not installed;

- domestic hot water (DHW) is prepared in the automated heat station of the building with the coefficient of efficiency of 0.95 ;

- the type of front door is two doors with a hallway in between; 
- the area of the external enclosure is $72 \mathrm{~m}^{2}$. This enclosure is glassed. Its thermal transmittance is $1.2 \mathrm{~W} /\left(\mathrm{m}^{2} \cdot \mathrm{K}\right)$, total solar energy transmittance is $g=0,5$, air permeability of the enclosure is $5.82 \mathrm{~m}^{3} /\left(\mathrm{m}^{2} \cdot \mathrm{h}\right)$, the enclosure is oriented southwards;

- duration of the heating season is from 1 October to 8 May, 220 days. Other parameters of the heating season are placed in the Table 1. Other quantities necessary for calculation are given in Table 2.

At first, calculations were performed for a commercial building, then the purpose of the building was changed and thus, the data of a cultural building and residential apartment house was obtained, i.e. the calculations were performed with the same building, only its purpose was changed.

The parameters are different according to building category, except indoor air temperature value.

The analysis of calculation's results according to the equation (1) and equation (29) are presented in Fig. 2-4.

In each building category analyzed monthly heat gains are significantly larger during the heating season, if the limit conditions are neglected.
The results of Fig. 2 diagram a indicate that if limit conditions of heat gains are not assessed, significantly higher heat gains during all months of the year is obtained than when calculating according to our proposed limit conditions. Thus, i.e. when limit conditions are not assessed, the difference between heat loss and heat gains in individual months of the year is negative (Fig. 2, diagram b, 2-5 and 10-12 months) - the building "produces” energy. Due to this "produced” energy, total annual energy consumption of the building is significantly lower (Fig. 2, diagram c, $13.11 \mathrm{kWh} /\left(\mathrm{m}^{2} \cdot\right.$ year)) than the one calculated including the limit conditions of heat gains (Fig. 3, diagram c, $39.39 \mathrm{kWh} /\left(\mathrm{m}^{2} \cdot\right.$ year)).

The calculation results presented in Fig. 3 are similar to Fig. 2. The results presented in Fig. 3 are distinguished by the fact that when limit conditions of heat gains were not assessed, the building "produced" such a large amount of energy that total annual energy consumption of the building was negative, i.e. various heat gains were sufficient to exceed all heat loss and energy needs for hot water and electric power (Fig. 3, diagram c $30.31 \mathrm{kWh} /\left(\mathrm{m}^{2} \cdot\right.$ year $\left.)\right)$.

Table 1. Parameters of heating season used in the calculations

\begin{tabular}{l|c|c|c|c|c|c|c|c}
\hline \multicolumn{1}{c|}{ Month } & 1 & 2 & 3 & 4 & 5 & 10 & 11 & 12 \\
\hline $\begin{array}{l}\text { Days of a considered month } n \text { of the heating } \\
\text { season, } T_{n, h . s .} \text { days }\end{array}$ & 31 & 28 & 31 & 30 & 8 & 31 & 30 & 31 \\
\hline $\begin{array}{l}\text { Average outdoor temperature per month } n \text { of } \\
\text { the heating season, }{ }^{\circ} \mathrm{C}\end{array}$ & -5.2 & -4.5 & -0.7 & 5.5 & 9.5 & 7.1 & 1.9 & -2.5 \\
\hline $\begin{array}{l}\text { Average duration of daylight hours for each } \\
\text { month } n \text { of the heating season, } t_{n, s}, \text { hours }\end{array}$ & 7.73 & 9.51 & 11.64 & 13.91 & 15.25 & 10.32 & 8.29 & 7.21 \\
\hline $\begin{array}{l}\text { Total solar energy amount per month } n \text { gener- } \\
\text { ated through } 1 \mathrm{~m}^{2} \text { of vertical surface of south } \\
\text { orientation, } q_{n, e}, \mathrm{kWh} /\left(\mathrm{m}^{2} \cdot \mathrm{month}\right)\end{array}$ & 15.7 & 45.5 & 87.3 & 84.6 & 24.6 & 45 & 20.3 & 19.3 \\
\hline
\end{tabular}

Table 2. The values of generalized parameters due to building categories used in the calculations

\begin{tabular}{|c|c|c|c|}
\hline Description of parameter & $\begin{array}{l}\text { Trade services } \\
\text { building }\end{array}$ & $\begin{array}{l}\text { Cultural } \\
\text { building }\end{array}$ & $\begin{array}{l}\text { Multi-apartment } \\
\text { building }\end{array}$ \\
\hline $\begin{array}{l}\text { Indoor air temperature during the heating season, } \theta_{i . w .},\left({ }^{\circ} \mathrm{C}\right),(\mathrm{prEN} \\
\text { 15203:2005) }\end{array}$ & 20 & 20 & 20 \\
\hline Specific area for one person $*, A_{o}\left(\mathrm{~m}^{2} /\right.$ person), (prEN 15203:2005) & 10 & 5 & 40 \\
\hline Heat flux from a person , $g_{o}$, (W/person), (prEN 15203:2005) & 90 & 80 & 70 \\
\hline Heat gains due to internal heat sources $*, g_{v},\left(\mathrm{~W} / \mathrm{m}^{2}\right)$ & 9 & 16 & 1,8 \\
\hline $\begin{array}{l}\text { Average time of people’s presence in a building during a day per month (the } \\
\text { same for all months), } t_{n},(\mathrm{~h}),(\text { prEN 15203:2005) }\end{array}$ & 4 & 3 & 12 \\
\hline $\begin{array}{l}\text { Average annual electricity consumption for } 1 \mathrm{~m}^{2} \text { of a building } *, \psi_{E} \text {, } \\
\left(\mathrm{kWh} /\left(\mathrm{m}^{2} \cdot \text { year }\right) \text { ), (prEN 15203:2005) }\right.\end{array}$ & 30 & 20 & 30 \\
\hline Part of the building area, where electricity is used, $f_{E}$, (prEN 15203:2005) & 0.8 & 0.8 & 0.7 \\
\hline $\begin{array}{l}\text { External air amount for ventilation of } 1 \mathrm{~m}^{2} \text { of building } *, v_{c},\left(\mathrm{~m}^{3} /\left(\mathrm{h} \cdot \mathrm{m}^{2}\right)\right) \text {, } \\
(\mathrm{prEN} 15203: 2005)\end{array}$ & 0.7 & 1 & 0.7 \\
\hline $\begin{array}{l}\text { Average annual energy consumption for DHW for } 1 \mathrm{~m}^{2} \text { of a building } * \text {, } \\
\psi_{h . w},\left(\mathrm{kWh} /\left(\mathrm{m}^{2} \cdot \text { year }\right)\right),(\text { prEN 15203:2005) }\end{array}$ & 10 & 10 & 20 \\
\hline
\end{tabular}

* The values indicated are related to the heated area of a considered building. 


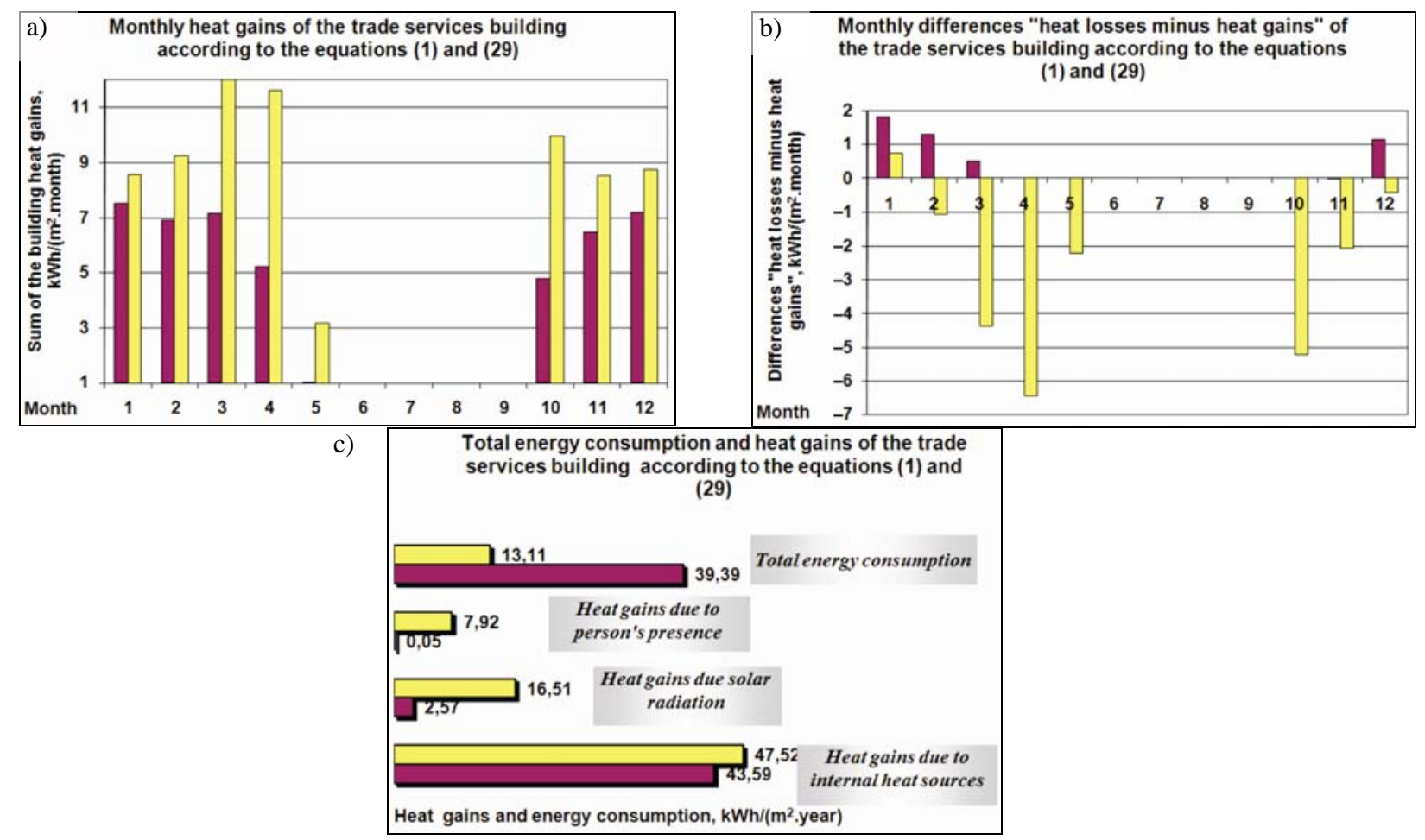

Fig. 2. Calculation results for the trade services building according to equations (1) and (29)

Calculation results according to equation (29), - Calculation results according to equation (1))

The attention should be paid to the data in Fig 3b, where according to the equation (29) the differences are almost minimal between the calculated values of heat losses and heat gains. In opposite, the difference between values got according to equation (1) is significant and shows energy surplus in the cultural building. Such situation occurs due to the fact that cultural buildings have especially high heat emissions from internal heat sources. In reality, such high emissions in these buildings are possible only when people are present in the building (during events). Meanwhile, standard calculation methods of heat emissions from internal heat sources are not differentiated with regard to time. In this case, it is expedient to distinguish between the heat emissions from internal sources of heat that occur when people are present in the building and heat emissions that occur throughout the day. Such division of the amounts of heat with regard to time would improve the precision of energy consumption calculations of other buildings.

Calculation results presented in Fig. 4 are distinguished by the fact that due to low heat emissions from internal heat sources in apartment houses, the heat gains into the building during winter and late autumn months of the year does not exceed the loss of heat and therefore, the assessment of limit conditions does not affect calculation results (Fig. 4, diagrams a and b). The differences in calculations occur only in the warmer months of the heating period, i.e. spring and early autumn months, when due to heat gains, surplus amounts of heat occur in the building (Fig. 5, diagrams a and b). However, even in this case, if the limit conditions of heat gains are not assessed, total annual energy consumption of the building (Fig. 4, diagram c, $62.75 \mathrm{kWh} /\left(\mathrm{m}^{2}\right.$ year $)$ ) is different from the consumption calculated including limit conditions of heat gains (Fig. 4, diagram c, $69.30 \mathrm{kWh} /\left(\mathrm{m}^{2}\right.$ year)) and this difference is approximately $10 \%$.

Moreover, the calculation of energy consumption of the above mentioned buildings was performed according to average annual parameters of the heating period. They established that when limit conditions of heat gains are not assessed, calculation results according to average annual and monthly climate parameters match; however, these results are incorrect as some of them indicate that the building is producing energy throughout the year, i.e. negative annual energy consumption of the building is obtained.

\section{The use of analysis' results}

The presented research results can be used in creating standardized requirements for assessment of time parameters of heat gains and creating normative limit conditions of inflow as well as for improvement of the calculation methods of energy performance of the buildings. In the process of creating the above mentioned standard requirements, it is expedient to elaborate on the types of heat gains, specifying the following normative data required for calculating the inflow:

normative schemes of heat gains into the building during the day, assessing the time of the presence of people in the building and the duration of daytime;

normative heat gains from internal heat sources that occur throughout the day in the buildings of different purposes;

the time of presence of people during daytime and nighttime in the buildings of various purposes; average duration of sunshine during various months of the heating period. 

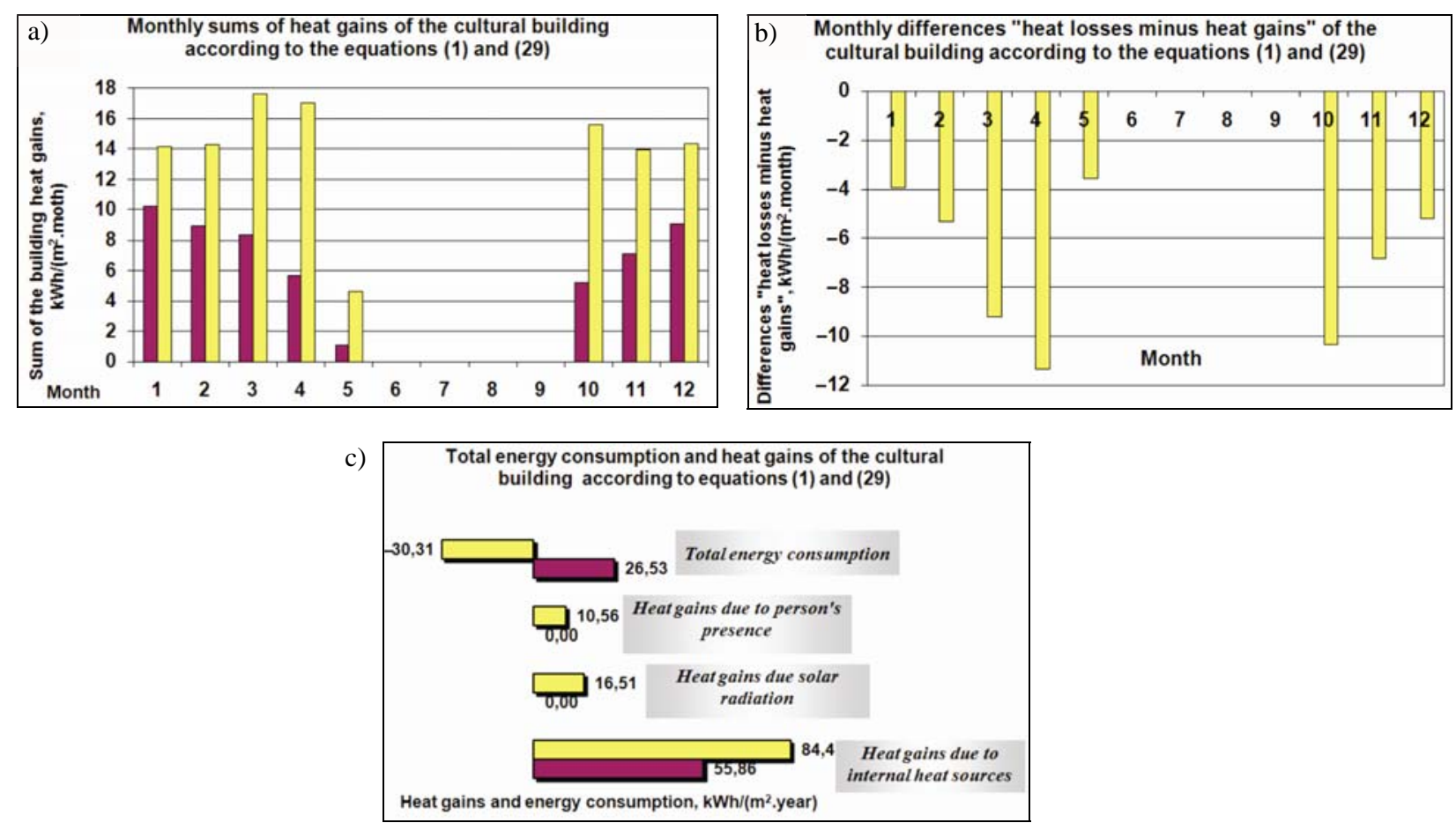

Fig. 3. Calculation results for the cultural building according to equations (1) and (29)

( - Calculation results according to equation (29), - Calculation results according to equation (1))
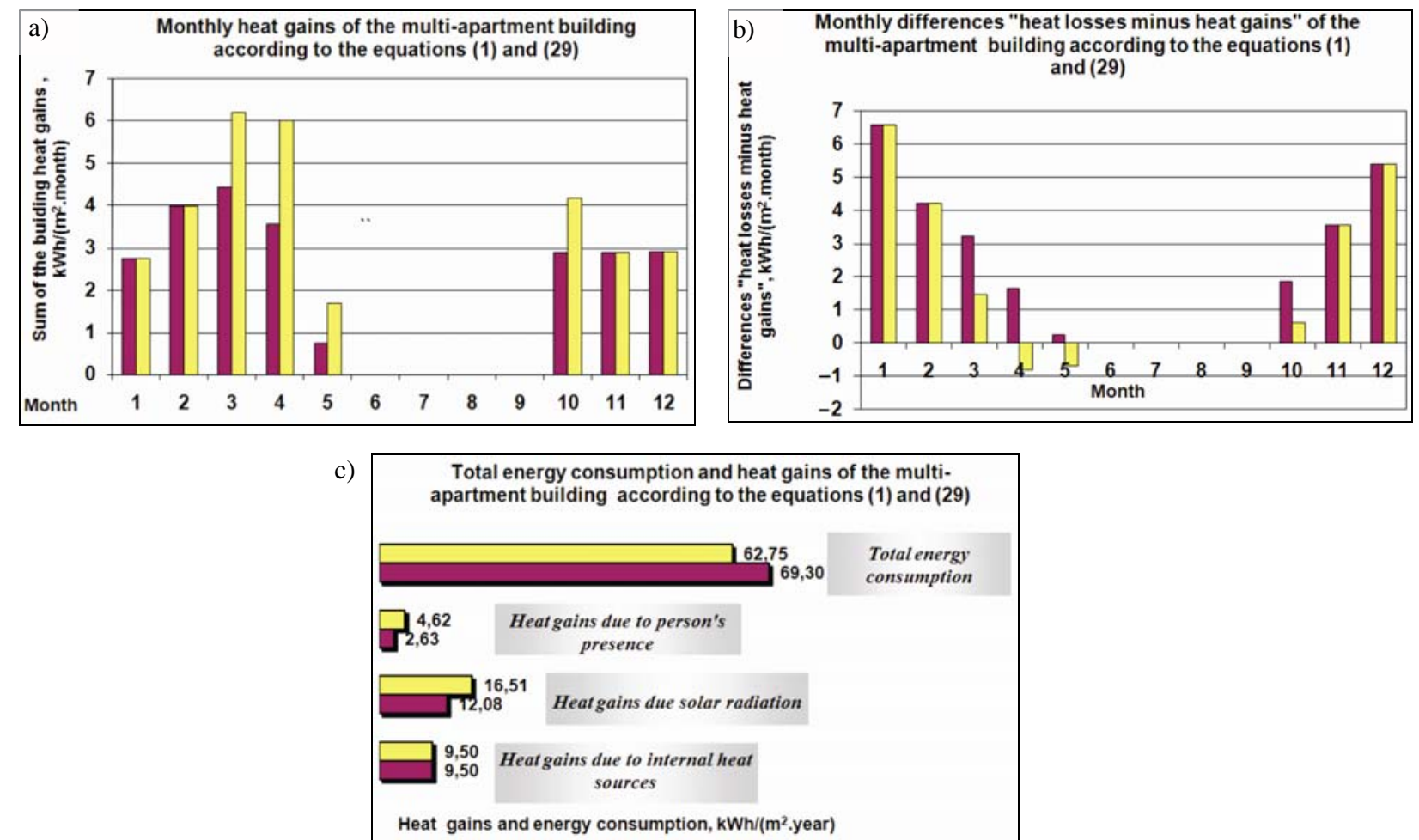

Fig. 4. Calculation results for the multi-apartment building according to equations (1) and (29)

( - Calculation results according to equation (29), - Calculation results according to equation (1)) 


\section{Conclusions}

1. Principal schemes of heat gains into the building during the day depending on the time of presence of people in the building and the duration of daytime were presented. These schemes describe the disadvantageous cases of heat gains, the same to the buildings of all purposes of use, and represent the principal attitude towards the time parameters of various heat gains into the buildings. The schemes are required as the first step in forming the limit conditions of heat gains.

2. According to the schemes of heat gains into the building, the equations were created, which describe the limit conditions of heat gains and check calculations of energy consumption in the buildings of various purposes were performed. The results of the calculations were presented. They indicate that the introduction of limit conditions have a significant impact on the calculation results of energy consumption in the building.

3. If calculations of energy performance certification for buildings are performed without regard to time parameters and limit conditions of heat gains into the building, it is possible that the negative difference between heat loss and heat gains in the building is obtained. It indicates that the building is producing energy during certain months of the heating period, and that is not possible.

4. If limit conditions of heat gains are not assessed, calculation results of energy consumption of the building according to average annual and monthly climate parameters match, but they do not represent the actual energy consumption in the building.

5. Assessment of limit conditions of heat gains in the building affect the calculation results of each month of the heating period and therefore, the calculations of energy performance certification for buildings should not and cannot be performed based on average annual parameters of the heating period.

\section{References}

Anderson, R.; Christensen, C.; Horowitz, S. 2006. Analysis of residential system strategies targeting least-cost solutions leading to net zero energy homes, ASHRAE Transactions Annual Meeting of the American-Society-of-HeatingRefrigerating-and-Air-Conditioning-Engineers, Quebec City, Canada, 2006, 112(2): 330-341.

Bazjanac, V. 2004. Building energy performance simulation as part of interoperable software environments, Building and Environment 39(8): 879-883. doi:10.1016/j.buildenv.2004.01.012

Beccali, M.; Caponio, R.; Ferrari, S.; Schultze, G. 1998. Assessing and monitoring the energy consumption of a large building stock by the means of a dynamic data-base, in 2nd European Conference on Shaping our European Cities for the 21st Century, Florence, Italy, Apr 01-03, 1998 Rebuild - The European Cities Of Tomorrow - Shaping Our European Cities For The 21st Century, 220-223.

Belindzeva-Korkla, O.; Kreslins, A. 2003. The limitation to the practical use of building heat loss coefficient in building energy certification, in Research in Building Physics, 2nd International Conference on Building Physics, Antwerp, Belgium, Sep 14-18, 2003, 619-624.
Biekša, D.; Martinaitis, V.; Šakmanas, A. A. 2002. An Estimation of Exergy Consumption Paterns of Energy-Intensive Building Service Systems, Journal of Civil Engineering and Management 12(1): 37-42.

Bolton, J. M.; Bell, D. 2002. Evaluating building performance using interval meter data, Solutions For Energy Security And Facility Management Challenges, in 25th World Energy Engineering Congress, Atlanta, Georgia, Oct 09-11, 2002, 447-455.

Brandtweiner, R.; Hoeltl, A. 2007. Implementation of the EU Directive on the energy performance of buildings in Austria, in 3rd International Conference on Sustainable Development and Planning. Algarve, Portugal, Apr 25-27, 2007 1-2(102): 525-534.

Brodrick, J. R.; Petrow, E. D.; Scholand, N. J. 2002. Lighting energy consumption trends and R \& D opportunities, in 2nd Conference on Solid State Lighting, Seattle, Washington, Jul 09-11, 2002Solid State Lighting II(4776): 9-17.

Colomban, M.; Zobec, M.; Kragh, M. 2001. An integrated design approach to the environmental performance of buildings, in 6th World Congress of the Council-on-TallBuildings-and-Urban-Habitat, "Tall Buildings and Urban Habitat-Cities in the Third Millennium", Melbourne, Australia, Feb 26-Mar 02, 2001, 583-601.

Corrado, V.; Fabrizio, E. 2006. A simplified calculation method of the annual energy use for space heating and cooling: Assessment of the dynamic parameters for the Italian building stock and climate, in 3rd International Building Physics Conference, "Research in Building Physics and Building Engineering”, Concordia Univ, Montreal, Canada, Aug 27-31, 2006, 645-653.

EN ISO 13790:2008 „Thermal performance of buildings. Calculation of energy use for space heating“.

Horne, R. 2006. International assessment of the environmental performance of housing, and prospects for sustainable cities, in 4th International Conference on Urban Regeneration and Sustainability "Sustainable City IV: Urban Regeneration And Sustainability”, Jul 17-19, Tallinn, Estonia, 2006, 29-38.

Ginevičius, R.; Podvezko, V.; Raslanas, S. 2008. Evaluating the alternative solutions of wall insulation by multicriteria methods, Journal of Civil Engineering and Management 14(4): 217-226. doi:10.3846/1392-3730.2008.14.20

Gorgolewski, M. T.; Liao, Z.; Clarida, R. 2006. Thermal mass in office buildings, in 3rd International Building Physics Conference "Research in Building Physics and Building Engineering”, Concordia Univ, Aug 27-31, Montreal, Canada, 2006, 689-694.

Gram-Hanssen, K.; Bartiaux, F.; Jensen, O. M.; Cantaert, M. 2007. Do homeowners use energy labels? A comparison between Denmark and Belgium, Energy Policy 35(5): 2879-2888. doi:10.1016/j.enpol.2006.10.017

Guan, L. 2006. Impact of climate change on energy uses and $\mathrm{CO}_{2}$ emissions from office buildings in Australia, in Proceedings of Criocm 2006 International Research Symposium on Advancement of Construction Management and Real Estate "International Research Symposium on Advancement of Construction Management, and Real Estate”, Nov 03-05, 2006, Beijing, Peoples R China, 1-2: 83-90.

Jurelionis, A.; Isevičius, E. 2008. CFD predictions of indoor air movement induced by cold window surfaces, Journal of Civil Engineering and Management 14(1): 29-38. doi:10.3846/1392-3730.2008.14.29-38 
Kaushika, N. D.; Kumar, P. 2004. Solar thermal simulations of buildings in cold climates using transparent insulation, in Proceedings 2nd International Conference on "Built Environment and Public Health (BEPH 2004)”, Dec 06-08, 2004, Shantou, Peoples R China, "Built Environment and Public Health", 238-248.

Kianifar, A.; Rezazadeh, M. 2006. An improved design method for estimating the annual auxiliary energy requirement for solar heating building, in 9th Arab International Conference on Solar Energy (AICSE-9), April 30, 2007, Bahrain, Nov 05-07, 2006, 209(1-3): 182-189.

Kreslins, A.; Belindzeva-Korkla, O. 2003. Certification of thermal performance of building's envelope, in Proceeding 4th Baltic Heater Transfer Conference "Advances in Heat Transfer Engineering”, Aug 25-27, Kaunas, Lithuania, 2003, 241-246.

Lin, Y.; Zmeureanu, R. 2006. Mathematical model of the thermal performance of a dome-covered house, in 3rd International Building Physics Conference "Research in Building Physics and Building Engineering” Aug 27-31, 2006, Concordia Univ, Montreal, Canada, 611-618.

LST EN 15217:2007 „Energy performance of buildings Methods for expressing energy performance and for energy certification of buildings“.

Manioglu. G.; Yilmaz, Z. 2006. Evaluation of thermal performance of traditional and modern residential buildings in the hot dry climatic zone of Turkey, in 3rd International Building Physics Conference "Research in Building Physics and Building Engineering” Aug 27-31, 2006, Concordia Univ, Montreal, Canada, 683-688.

Mladin, E. C.; Vasilescu, E.; Serban, R. 2006. Assessment of national potential for energy savings and greenhouse gas reduction by inverse analysis of building energy performance, in Proceedings of the 19th International Conference on Efficiency, Cost, Optimization, Simulation and Environmental Impact of Energy Systems, Vol. 2006, 19th International Conference on Efficiency, Cost, Optimization, Simulation and Environmental Impact of Energy Systems (ECOS 2006), Jul 12-14, 2006, Aghia Pelagia, Greece, 1-3: 855-860.

Pappas, A.; Loew, E.; Scotland-Stewart, T.; Krarti, M. 2006. Impact of shape on residential buildings energy performance, in International Solar Energy Conference 2005, Aug 06-12, 2005, Orlando, 105-111.

prEN 15203:2005 „Energy performance of buildings. Assessment of energy use and definition of ratings“.

Pulselli, F. M.; Pulselli, R. M.; Simoncini, E. 2006. Environmental accounting of buildings: outcomes from the energy analysis, in 4th International Conference on Urban Regeneration and Sustainability, Jul 17-19, Tallinn, Estonia, 489-498.

Reddy, T. A. 2006. Literature review on calibration of building energy simulation programs: Uses, problems, procedures, uncertainty, and tools, in Winter Meeting of the AmericanSociety-of-Heating-Refrigerating-and-Air-ConditioningEngineers “ASHRAE TRANSACTIONS” 2006, Chicago, I, 112(1): 226-240.

Richalet, V.; Neirac, F. P.; Tellez, F.; Marco, J.; Bloem, J. J. 2001. HELP (house energy labeling procedure): methodology and present results, Energy and Buildings 33(3): 229-233. doi:10.1016/S0378-7788(00)00086-4
Šeduikytė, L.; Paukštys, V. 2008. Evaluation of indoor environment conditions in offices located in buildings with large glazed areas, Journal of Civil Engineering and Management 14(1): 39-44. doi:10.3846/1392-3730.2008.14.39-44

Stankevičius, V.; Karbauskaitė, J.; Bliūdžius, R. 2002. Analysis of Energy Consumption in Apartment Buildings, Energetika 2: 57-61.

Stankevičius, V.; Karbauskaite, J. 2000. The Comparison of a Real Energy Demand to the Design Power of Heating Systems in Apartment Buildings, Civil Engineering 6(5): 366370.

Stankevicius, V.; Karbauskaite, J.; Monstvilas, E. 2007. The development of reference values for energy certification of buildings in Lithuania, Energy and Buildings 39(3): 284-288. doi:10.1016/j.enbuild.2006.05.008

Stegou-Sagia, A.; Antonopoulos, K. A.; Angelopoulou, C. 2005. Thermal comfort and energy use, in Procceedings International Conference on Efficiency, Cost, Optimization, Simulation and Environmental Impact of Energy Systems (ECOS 2005), Jun 20-22, 2005, Trondheim, Norway, 1-3: 911-918.

Teodosiu, C.; Colda, I.; Lungu, C.; Damian, A. 2006. Simulation of HVAC systems energy consumption, in First International Symposium on Environment Identities and Mediterranean Area 1-2: 192-196.

Waide, P. 1996. Appliance energy labelling and efficiency standards in Europe, in Advanced Research Workshop on Development with Sustainable Use of Electricity, Jun 1721, 1996, Lopuszna, Poland, 56: 237-286.

Wei, Z. T.; Zmeureanu, R. 2006a. Second law analysis of HVAC systems for office buildings, in 3rd International Building Physics Conference, Concordia Univ, Montreal, Canada, Aug 27-31, 2006, Research In Building Physics And Building Engineering, 571-578.

Wei, Z. T.; Zmeureanu, R. 2006b. Second law analysis of HVAC systems for office buildings, in 3rd International Building Physics Conference Research in Building Physics and Building Engineering, Aug 27-31, 2006, Concordia Univ, Montreal, Canada, 571-578.

Wouters, P.; Van Orshoven, D.; Vandaele, L.; Schietecat, J. 2003. The scientific and technological challenges of buildings regulations in relation to a correct performance assessment of the energy performance and Indoor Climate in Buildings, in 2nd International Conference on Building Physics "Research in Building Physics", Sep 14-18, 2003, Antwerp, Belgium, 665-670.

Xie, L. H.; Liu, X. J. 2006. Countermeasure research on residential building saving energy based on sustainable development, in Proceedings of 2006 International Conference on Construction \& Real Estate Management, "Collaboration and development in construction and real estate”, Oct 05-06, 2006, Orlando, 1-2: 391-394.

Zavadskas, E. K.; Kaklauskas, A.; Turskis, Z.; Tamošaitienė, J. 2008. Selection of the effective dwelling house walls by applying attributes values determined at intervals, Journal of Civil Engineering and Management 14(2): 85-93. doi:10.3846/1392-3730.2008.14.3 


\section{ŠILUMOS PRITEKĖJIMAI PASTATUOSE - BŪTINOS RIBINĖS SĄLYGOS ŠILUMOS REŽIMUI SKAIČIUOTI}

\section{E. Monstvilas, K. Banionis, V. Stankevičius, J. Karbauskaitė, R. Bliūdžius}

\section{Santrauka}

Straipsnyje pateiktų tyrimų rezultatai susieti su tais atvejais, kai pastatų energinis naudingumas ịvertinamas skaičiavimo būdu, neatsižvelgiant ị realius pastato energijos suvartojimo rodiklius. Energijos sąnaudos pastato vėsinimui neịvertintos. Jei pastatas gerai apšiltintas, jo šilumos nuostoliai gali būti mažesni už suminius pritekančios šilumos kiekius. Dabartiniu metu skaičiuojant pastato energijos sąnaudas ivertinami visi pritekančios šilumos kiekiai, išsiskiriantys pastate ar i ji patenkantys iš išorès. Kol kas neaptarti laikiniai pritekančios šilumos i pastatą parametrai, neaptartos ribinės sąlygos, pagal kurias turi būti nustatyti perteklinė pritekanti šiluma ir pritekančios šilumos kiekiai, kuriuos būtina vertinti skaičiuojant pastato energijos sąnaudas. Todèl skirtumas tarp pastato šilumos nuostolių ir pritekančios šilumos kiekiu gali būti minusinis, t. y. pastatas pradeda gaminti energiją. Darbe pateiktos autorių sudarytos principinės pritekančios šilumos kiekiu i pastatą schemos per para, priklausomai nuo žmonių buvimo pastate tą para, ir šviesaus paros laikotarpio trukmès. Sudarant šias schemas, pasirinktas pats nepalankiausias pritekančios šilumos atvejis, bendras visų naudojimo paskirčiu pastatams. Pagal šias schemas sudarytos formulès, apibūdinančios ribines šilumos pritekejjimo sąlygas, ir pagal jas buvo atlikti i̇vairios paskirties pastatų kontroliniai energijos sąnaudų skaičiavimai pagal šildymo sezono vidutinius mènesio rodiklius. Šių skaičiavimų rezultatai rodo, kad šilumos pritekejjimo i̇ pastatą ribinių sąlygų ivvertinimas daro didelę įtaką pastato energijos sąnaudų skaičiavimų rezultatams. Svarbu, kad pastatų energinio naudingumo sertifikavimo skaičiavimo metodikos būtų paremtos tais pačiais pastatų energijos suvartojimo vertinimo principais. Straipsnyje autorių pateiktos šilumos pritekèjimo ribinès sąlygos galètų būti panaudotos tikslinant skaičiavimo metodikos principus pastatų energiniam naudingumui ivertinti.

Reikšminiai žodžiai: pastatas, energinis naudingumas, energijos suvartojimas, energijos suvartojimo schemos, sertifikavimas, pritekanti šiluma, šilumos nuostoliai, šilumos pritekejjimo ribinès sąlygos.

Edmundas MONSTVILAS. Doctor, senior researcher at the Laboratory of Thermal Building Physics in the Institute of Architecture and Construction, KTU. Research interests: thermal processes in building, thermal and moisture properties of building materials and elements.

Karolis BANIONIS. Ph.D. student at the Institute of Architecture and Construction, KTU. Research interests: thermal processes in buildings, thermal and moisture properties of building materials and elements.

Vytautas STANKEVIČIUS. Doctor Habil, full Professor, chief researcher at the Laboratory of Thermal Building Physics in the Institute of Architecture and Construction, KTU. Research interests: heat transfer, technical properties of thermal insulation products.

Jūratė KARBAUSKAITE். Doctor, senior researcher at the Laboratory of Thermal Building Physics in the Institute of Architecture and Construction, KTU. Research interests: thermal processes in buildings, thermal properties of building materials and elements, heating and ventilation systems.

Raimondas BLIŪDŽIUS. Doctor, head of Laboratory of Thermal Building Physics in the Institute of Architecture and Construction, KTU. Research interests: thermal processes in buildings, thermal properties of building materials and elements. 